\title{
PENGARUH PENAMBAHAN SLUDGE LIMBAH PENGOLAHAN LINDI TERHADAP DATA ANALISIS PROKSIMAT DAN NILAI KALOR BRIKET ARANG LIMBAH BIOMASSA
}

\author{
Made Gunamantha1, Gede Eka Budi Darmawan² \\ 1Jurusan Analis Kimia, Universitas Pendidikan Ganesha \\ Singaraja, Indonesia \\ 2Jurusan Penjaskesrek, Universitas Pendidikan Ganesha \\ Singaraja, Indonesia \\ E-mail:md_gunamantha@yahoo.com
}

\begin{abstract}
Abstrak
Penelitian ini dilakukan untuk mengetahui pengaruh penambahan sludge terhadap data analisis proksimat dan nilai kalor briket arang limbah biomassa. Sampel sludge diperoleh dari fasilitas pengolahan lindi di tempat penimbunan akhir (TPA) Bengkala Singaraja. Limbah bambu dan jerami yang digunakan, diperoleh dari pengerajin bambu dan lahan pertanian di sekitar di kota Singaraja. Sampel sludge dikeringkan di bawah sinar matahari selama 3 (tiga) hari, ditumbuk hingga halus, dan diayak dengan saringan 25 mesh. Limbah bambu dipotong kecil-kecil hingga panjang dan lebar maksimal $3 \times 3 \mathrm{~cm}$ sedangkan jerami dipotong-potong hingga panjang makismalnya $10 \mathrm{~cm}$. Selanjutnya kedua limbah biomassa tersebut diarangkan secara terpisah. Arang yang diperoleh ditumbuk dan diayak dengan saringan 25 mesh. Briket dibuat dari masing-masing arang tersebut dengan variasi penambahan sludge $0 \%, 4 \%, 8 \%, 12 \%, 16 \%, 20 \%, 24 \%, 28 \%, 32 \%, 36 \%$, dan $40 \%$. Hasil dari penelitian ini menunjukkan bahwa penambahan sludge mengakibatkan peningkatan kadar abu pada briket dan penurunan pada kadar volatile matter dan nilai kalornya.
\end{abstract}

Kata kunci : sludge, jerami, bambu, briket, nilai kalor

\begin{abstract}
This study was conducted to determine the effect of sludge on proximate analysis data and the calorific value of bamboo and straw charcoal briquettes. Sludge samples were obtained from the leachate treatment facility at the landfill (TPA) Bengkala Singaraja. Bamboo and straw waste were obtained from bamboo craftsmen and agricultural land around the city of Singaraja. Sludge samples were dried under sun for 3 (three) days, finely ground, and sieved to 25 mesh. Waste bamboo cut into small pieces to a maximum length and width of $3 \times 3 \mathrm{~cm}$, while the straw was cut to maximum length $10 \mathrm{~cm}$. Furthermore, both of them were carbonized separately. Charcoal were pulverized and sieved to 25 mesh. Briquettes were made from each charcoal by combining with variation sludge $0 \%, 4 \%, 8 \%, 12 \%, 16 \%, 20 \%, 24 \%, 28 \%$, $32 \%, 36 \%$, and $40 \%$. Results from this study showed that the addition of sludge increased the ash content and decreased the volatile matter and calorific value of the briquettes.
\end{abstract}

Keywords : Sludge, straw, bamboo, briquette, calorific value

\section{PENDAHULUAN}

Lumpur limbah perkotaan (sewage slude) adalah residu yang dihasilkan dari proses pengolahan air limbah sebagai hasil dari pengolahan air limbah dari berbagai sumber seperti rumah tangga, industri, fasilitas umum, dan limpasan jalan. Lumpur limbah dapat dihasilkan dari tahapan 
pengolahan primer (fisik dan/atau kimia), selama tahapan sekunder (pengolahan secara biologi), maupun tersier (fisika dan/atau kimia). Penanganan lumpur ini merupakan masalah lingkungan yang serius di seluruh dunia (Kolat, and Kadlec, 2013). Selama ini, ditangani dengan memanfaatkannya sebagai tanah urug penimbunan sampah perkotaan atau dibuang ke laut (Rulkens, 2008). Akan tetapi, karena besarnya jumlah lumpur upaya tersebut menjadi tidak efektif. Adapun pengolahan terhadap lumpur limbah ini diperkirakan menimbulkan biaya $50 \%$ dari biaya pengolahan air limbah darimana lumpur itu dihasilkan (Rulkens, 2008). Lumpur limbah perkotaan merupakan campuran heterogen dari komponen organik (karbohidrat, protein, lemak) dan inorganik (kalium, kalsium, fosfor, besi, dll) sesuai dengan asal limbahnya (Kolat and Kadlec, 2013, Werle, 2013). Komponen organik adalah kandungan utama limbah perkotaan sehingga memiliki potensi untuk dimanfaatkan sebagai sumber energi (Werle, 2013). Dalam konteks pemungutan energi dari lumpur limbah, Rulkens (2008) menegaskan bahwa terdapat beberapa pilihan pengolahan meliputi penguraian secara anaerobik, penguraian bersama (codigestion), insinerasi dengan pemungutan energi, pirolisis, dan gasifikasi. Khusus untuk tiga pilihan terakhir atau dengan metode konversi thermal dilakukan pengeringan dulu terhadap lumpur limbah.

Saat ini, perhatian terhadap proses insinerasi lumpur limbah untuk pemulihan energi telah mengalami peningkatan. Dalam hal ini, jumlah energi yang dapat dipulihkan tergantung pada kandungan air dari lumpur, modifikasi dan kinerja insenerasi, dan proses pengeringan. Khusus untuk upaya pengurangan kadar air dapat ditempuh melalui pembriketan lumpur limbah atau sebagai komponen campuran bahan baku briket dengan limbah biomassa. Pada sisi lain, kepadatan yang rendah dalam biomassa dapat ditingkatkan dengan penambahan lumpur limbah. Demikian pula, nilai kalor yang rendah dalam lumpur limbah dapat ditingkatkan oleh keberadaan biomassa dari turunan tanaman langsung. Bertolak dari hal tersebut, bila biomassa dan lumpur limbah perkotaan tersebut dicampur dalam proporsi yang tepat, diduga dapat menyelesaikan persoalan dalam memanfaatkannya sebagai sumber energi alternatif sekaligus mengatasi persoalan lingkungan.

Berbagai penelitian terkait pembriketan biomassa telah dilakukan seperti, pembriketan limbah pertanian (Pallavi, et.al., 2013), sampah (Poespawati dan Mustiadi, 2012), limbah padat dari industri minyak goreng (Suhartini, et. al., 2011), limbah biji jarak (Sriharti dan Salim, 2011), limbah pertanian dan rumput (Ismaila, et. al., 2013), limbah gergaji kayu dengan penambahan pasta kertas (Akintunde dan Seriki, 2013). Namun demikian, upaya pemanfaatan biomassa lainnya seperti lumpur limbah perkotaan belum mendapatkan perhatian.

Penelitian ini bertujuan untuk mengetahui pengaruh penambahan lumpur limbah perkotaan terhadap data analisis proksimat dan nilai kalor (higher heating value, HHV) briket komposit yang dihasilkan dari lumpur limbah perkotaan dengan arang bambu dan jerami. Bambu dan jerami dipilih sebagai representasi dari biomassa turunan tanaman.

\section{METODE}

Penelitian ini menggunakan metode eksperimen. Sampel lumpur limbah perkotaan (sludge) diperoleh dari fasilitas pengolahan lindi di tempat penimbunan akhir (TPA) Bengkala Singaraja. Limbah bambu maupun jerami diperoleh dari pengerajin bambu dan lahan pertanian di sekitar kota Singaraja. Sampel sludge dikeringkan di bawah sinar matahari selama 3 (tiga) hari, ditumbuk hingga halus, dan diayak dengan saringan 25 mesh. Limbah bambu dipotong kecil-kecil hingga panjang dan lebar maksimal $3 \times 3 \mathrm{~cm}$ sedangkan jerami dipotong-potong hingga panjang makismalnya $10 \mathrm{~cm}$. Selanjutnya kedua limbah biomassa tersebut diarangkan secara terpisah. Arang yang diperoleh ditumbuk dan diayak dengan saringan 25 mesh. Briket dibuat dari masing-masing arang tersebut dengan variasi penambahan sludge $0 \%, 4 \%, 8 \%, 12 \%, 16 \%, 20 \%, 24 \%$, $28 \%$, 32\%, 36\%, dan $40 \%$. 
Pengujian bahan baku briket yaitu lumpur limbah, limbah bambu, limbah kayu sengon, dan sekam padi dikarakterisasi dengan parameter uji meliputi kadar air, kadar abu, bahan mudah melayang, dan nilai kalornya dengan metode ASTM. Pengujian Kandungan air ditentukan dengan standar ASTM D 3173-87, volatile matter ditentukan dengan standar ASTM D 3175-89, kandungan abu ditentukan dengan standar ASTM D 3174-89, dan kandungan fixed carbon dihitung berdasarkan perbedaan dengan mengacu pada ASTM D 317273. Adapun HHV ditentukan berdasarkan pada standar ASTM D 5865-85 dengan menggunakan Bomb Calorimeter. Karakterisasi dilakukan di Laboratorium Teknologi Mineral dan Batubara Bandung. Data kualitas briket yang diperoleh dibandingkan dengan standar kualitas briket menurut standar nasional Indonesia (SNI) dan peraturan menteri Energi dan Sumber Daya Mineral tentang kualitas briket arang..

\section{HASIL DAN PEMBAHASAN}

Hasil dari penelitian ini ditunjukkan pada Tabel 1 dan 2. Tabel 1 menunjukkan data analisis proksimat dan nilai kalor dari masing-masing variasi komposisi arang bambu-lumpur, sedangkan Tabel 2 menunjukkan data analisis proksimat dan nilai kalor dari masing-masing variasi komposisi arang jerami-lumpur. Pada Tabel 1 dan 2, BT dan ST berturut-turut menunjukkan kombinasi antara arang bambu-lumpur dan arang jerami-lumpur. Adapun angka dibelakangnya menunjukkan persentase komposisi lumpur dalam campuran.

Tabel 1. Data Analisis Proksimat dan Nilai Kalor dari masing-masing Variasi Komposisi Arang Bambu-Lumpur

\begin{tabular}{lcccccc}
\hline No & $\begin{array}{c}\text { Komposisi } \\
(\%)\end{array}$ & $\begin{array}{c}\text { Mc } \\
\%\end{array}$ & $\begin{array}{c}\text { Ash } \\
\%\end{array}$ & $\begin{array}{c}\text { VM } \\
\%\end{array}$ & $\begin{array}{c}\text { FC } \\
\%\end{array}$ & $\begin{array}{c}\text { HHV } \\
\text { MJ/kg }\end{array}$ \\
\hline 1 & BT40 & 5,66 & 39,65 & 16,31 & 38,38 & 15.89 \\
2 & BT36 & 5,69 & 36,24 & 16,56 & 41,51 & 17.08 \\
3 & BT32 & 5,93 & 32,05 & 17,31 & 44,71 & 18.50 \\
4 & BT28 & 6,20 & 29,27 & 17,82 & 46,71 & 19.26 \\
5 & BT24 & 6,05 & 26,74 & 17,46 & 49,75 & 20.30 \\
6 & BT20 & 5,97 & 24,80 & 16,61 & 52,62 & 21.19 \\
7 & BT16 & 6,45 & 21,19 & 19,64 & 52,72 & 21.94 \\
8 & BT12 & 6,59 & 19,17 & 18,72 & 55,52 & 22.77 \\
9 & BT8 & 6,87 & 16,29 & 20,44 & 56,40 & 23.74 \\
10 & BT4 & 6,47 & 14,03 & 20,87 & 58,63 & 24.57 \\
11 & BT0 & 6,34 & 14,88 & 17,48 & 61,30 & 24.96 \\
\hline
\end{tabular}

Tabel 2. Data Analisis Proksimat dan Nilai Kalor dari masing-masing Variasi Komposisi Arang Jerami-Lumpur

\begin{tabular}{lcccccc}
\hline No & $\begin{array}{c}\text { Komposisi } \\
\%\end{array}$ & $\begin{array}{c}\text { Mc } \\
\%\end{array}$ & $\begin{array}{c}\text { Ash } \\
\%\end{array}$ & $\begin{array}{c}\text { VM } \\
\%\end{array}$ & $\begin{array}{c}\text { FC } \\
\%\end{array}$ & $\begin{array}{c}\text { HHV } \\
\text { MJ/kg }\end{array}$ \\
\hline 1 & ST40 & 5,39 & 62,09 & 14,87 & 17,65 & 7.65 \\
2 & ST36 & 5,56 & 60,60 & 15,24 & 18,60 & 8.27 \\
3 & ST32 & 5,15 & 59,96 & 16,52 & 18,37 & 8.60 \\
4 & ST28 & 5,71 & 58,42 & 16,32 & 19,55 & 8.76 \\
5 & ST24 & 5,46 & 57,36 & 15,68 & 21,50 & 9.53 \\
6 & ST20 & 5,65 & 56,70 & 15,15 & 22,50 & 9.74 \\
7 & ST16 & 5,45 & 55,67 & 15,33 & 23,55 & 10.21 \\
8 & ST12 & 5,68 & 54,71 & 15,16 & 24,45 & 10.66 \\
9 & ST8 & 5,58 & 52,54 & 15,70 & 26,18 & 11.41 \\
10 & ST4 & 5,55 & 53,69 & 15,24 & 25,52 & 11.57 \\
11 & ST0 & 4,97 & 50,96 & 16,60 & 27,47 & 11.94 \\
\hline
\end{tabular}


Analisis proksimat adalah
prosedur analisis yang telah distandarisasi yang berupaya untuk mengkuantifikasi beberapa karakteristik fisik kunci dari biomassa atau bahan bakar padat yang dapat mempengaruhi karakteristik pembakarannya. Analisis tersebut mempertimbangkan biomassa terdiri dari empat komponen utama yakni kadar air (moisture content), bahan mudah melayang (volatile matter), abu (ash), dan karbon terikat (fixed carbon) serta menentukan proporsi relatif dari masing-masing parameter-parameter tersebut.

Seperti yang ditunjukkan pada Gambar 1, kandungan air dari briket relatif sama untuk semua kombinasi briket arang bambu dengan lumpur. Kadar air dari arang bambu yang dihasilkan adalah $6,34 \%$, sedangkan nilai kadar air tertinggi dari briket komposit ini adalah $6,87 \%$, yakni yang dihasilkan dengan penambahan lumpur $8 \%$. Adapun kadar air terendah ditunjukkan oleh komposisi dengan penambahan lumpur $40 \%$ yakni dengan kadar air 5,66\%. Untuk komposisi dengan penambahan lumpur $4 \%, 12 \%$, $16 \%$, 20\%, 24\%, 28\%, 32\%, dan 36\% memberikan kadar air masing-masing adalah $6,47 \%, 6,59 \%, 6,45 \%, 5,97 \%$, $6,05 \%, \quad 6,20 \%, \quad 5,93 \%$ dan $5,69 \%$ seperti pada Gambar 1.

Berbeda hallnya pada briket yang dihasilkan dari berbagai kombinasi antara arang jerami dengan lumpur, kadar air yang dihasilkan sangat variatif yakni $4,97 \%$ yang terendah dan tertinggi mencapai 5,71\% (Gambar 2). Kadar air yang ditunjukkan dari komposisi arang jerami dengan lumpur memberikan nilai yang lebih variatif. Kadar air dari briket arang jerami tanpa penambahan lumpur adalah 4,97\%. Nilai ini merupakan kadar air terendah dibandingkan dengan briket arang jerami dengan penambahan lumpur. Nilai tertinggi ditunjukkan oleh komposisi dengan penambahan lumpur $28 \%$ yakni dengan kadar air 5,715. Untuk komposisi dengan penambahan lumpur $4 \%, 8 \%, 12 \%, 16 \%, 20 \%, 24 \%$, $32 \%$, 36\%, dan $40 \%$ memberikan kadar air masing-masing adalah 5,55\%, $5,58 \%, 5,68 \%, 5,45 \%, 5,65 \%, 5,46 \%$, 5,15\%, 5,56\%, dan 5,39\% (Gambar 1).

Kadar air briket komposit berbeda signifikan secara statistic antara briket yang dihasilkan dari komposit arang bambu-lumpur dengan komposit arang jerami-lumpur seperti yang ditunjukkan pada Gambar 1 dan 2. Menurut Riley (2007), kadar air yang tinggi memberikan hasil nilai kalori rendah. Tampaknya benar di mana briket arang memiliki kadar air yang lebih rendah cenderung memiliki nilai kalor bruto lebih tinggi. Selain mempengaruhi nilai kalor, Briket arang dengan kadar air yang tinggi akan menyebabkan keretakan dan disintegrasi briket (Singh, 2004). Umumnya, arang segar dari pengarangan memiliki kadar air kurang dari $1 \%$ tetapi dapat menyerap kadar air dari kelembaban udara dalam waktu yang cepat dan dapat menyerap air sekitar 5 - 10\% (FAO, 1987). Spesifikasi kualitas briket arang biasanya membatasi kadar air antara 5 sampai 15\% (FAO, 1985) sedangkan kualitas arang yang baik harus memiliki kadar air tidak lebih dari $10 \%$. Di sisi lain, ada beberapa hasil kajian bahwa arang dengan kadar air yang lebih tinggi dari $10 \%$ cenderung hancur bila dipanaskan dalam tanur tinggi (FAO, 1987). Menurut FAO (1985) bahwa nilai kadar air dari arang yang dihasilkan dari kayu keras tropis adalah berkisar 5,4\% sedangkan kadar air arang dalam percobaan ini berkisar 5,66\% hingga $6,87 \%$ untuk briket komposit arang bambu-lumpur dan 5,15\% - 5,68\% untuk briket komposit arang jerami-lumpur. Kedua nilai tersebut masuk dalam kriteria yang dtentukan oleh FAO (1987), SNI dan peraturan menteri Energi dan Sumber Daya Mineral. Dengan kata lain arang yang dihasilkan memiliki pori yang relatif kecil. 


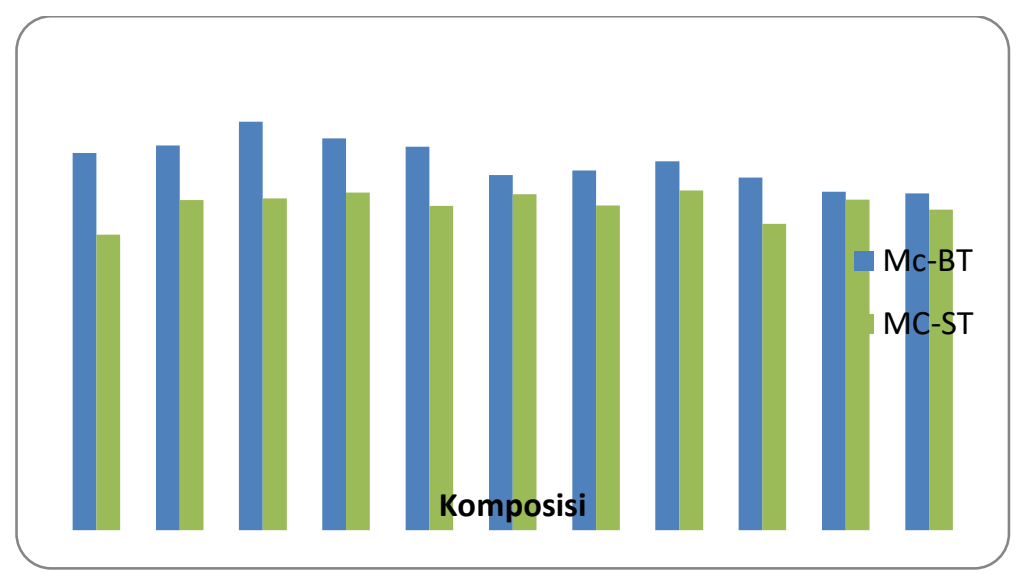

Gambar 1. Kadar Air Briket Komposit

Kandungan VM dalam sampel adalah bahan-bahan yang akan menguap bila sampel dikeringkan dalam temperatur, waktu, dan aliran udara terkendali. VM dalam bentuk gas atau uap tetapi tidak termasuk uap air. VM menentukan kemampuan pirolisi dari bahan bakar. VM yang tinggi berarti bahwa sebagian besar energi akan dilepas sebagai uap/gas pembakaran (Wang, et al., 2000).

VM dalam briket komposit arang bambu dan lumpur cenderung semakin kecil dengan penambahan lumpur yang semakikn besar. Dalam penelitian ini, VM terendah yang dicapai dari briket komposit arang bambu- lumpur adalah $14,87 \%$ dan yang tertinggi adalah $16,52 \%$ masing-masing dengan komponen lumpur $40 \%$ dan $4 \%$ (Gambar 2). Proporsi zat mudah terbang (VM) dalam komposit arang jeramilumpur cukup bervariasi antara komposisi satu dengan lainnya. Tidak terlihat pola yang jelas dalam perubahan VM terhadap variasi komposisi antara arang jerami-lumpur. VM terendah yang dicapai dari briket komposit arang jerami-lumpur adalah $16,31 \%$ dan yang tertinggi adalah 20,87\% masing-masing dengan komponen lumpur $40 \%$ dan $32 \%$ (Gambar 4). Menurut FAO (1985) zat terbang di arang dapat bervariasi dari nilai yang tertinggi (40\%) hingga yang lebih rendah ke $5 \%$ atau hingga kurang dari 5\% (FAO, 1985). Kualitas arang yang baik harus memiliki rentang zat terbang $20-25 \%$ (FAO, 1987). Briket komposit arang bambu-lumpur memiliki VM tertinggi $16,52 \%$ dibandingkan dengan briket komposit arang jerami-lumpur dengan kandungan VM 20,87\%. Adapun menurut SNI kadar VM ditetapkan 15\%, standar Jepang menetapkan $15-30 \%$, Inggris menetapkan 16,4 \%, dan Amerika menetapkan 19-28\%. Dengan mengacu pada kriteria-kriteria tersebut maka briket yang dihasilkan dari percobaan ini dapat dikatakan memenuhi spesifikasi kadar aspek kandungan VM.

Menurut FAO (1985) nilai zat terbang dari arang yang dihasilkan dari kayu keras tropis berkisar antara $17,1 \%$ hingga $23,6 \%$. Dalam percobaan ini, zat terbang terendah briket arang komposit adalah $14,87 \%$ dan $16,31 \%$ masingmasing untuk komposit arang bambulumpur dan jerami-lumpur. Bahan bakar padat dengan kandungan VM yang rendah, sangat sulit untuk menyalakannya dalam furnace. Bahan bakar padat dengan nilai VM yang lebih tinggi cenderung lebih kuat, lebih berat, lebih keras dan lebih mudah untuk pengapian dibandingkan briket dengan VM rendah. Oleh karena itu, dengan VM tinggi lebih mudah untuk menyalakannya tetapi menghasilkan api yang lebih berasap sementara briket dengan VM rendah sulit untuk menyalakannya namun dalam pembakarannya menghasilkan sedikit asap (Jenkins et. al., 1998). Oleh karena itu, arang dengan VM tinggi akan lebih baik digunakan untuk arang domestik seperti untuk bakar ikan sementara pemanfaatan dalam industri manufaktur akan lebih dipilih arang dengan VM rendah. VM yang rendah dimungkinkan 
karena tingginya kandungan bahan- bahan bakar. bahan yang tidak dapat dibakar dalam

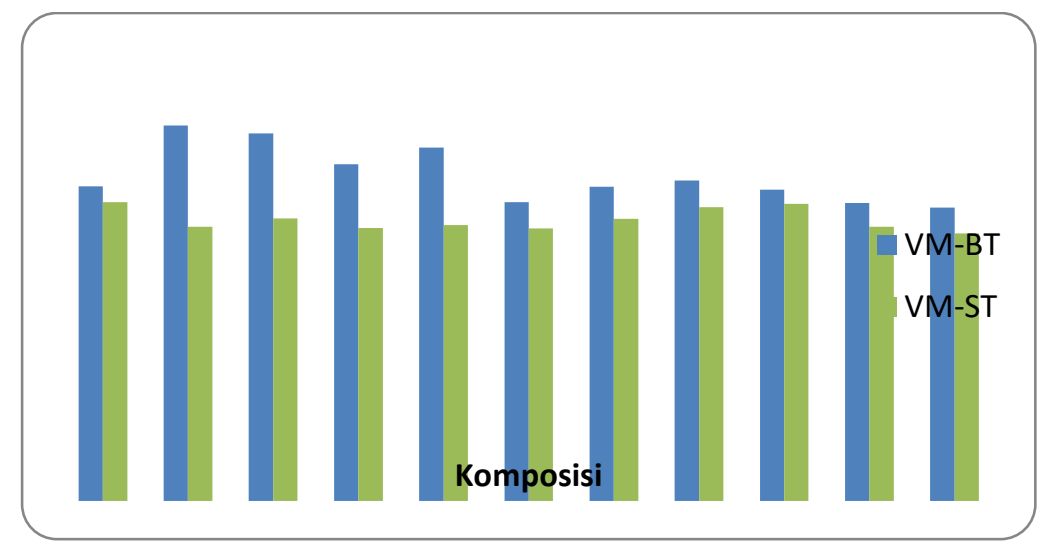

Gambar 2 .Kadar Volatile Matter Briket Komposit

Kadar abu (ash) berkaitan dengan VM dimana abu adalah residu yang tersisa setelah pembakaran bahan bakar. Kadar abu adalah bahan-bahan yang tidak mudah dan tidak tebakar dalam bahan bakar. Kadar abu yang tinggi pada bahan bakar akan menghasilkan potensi polutan lingkungan yang tinggi (Jenikins et al., 1998). Jenkins et al. (1998) mendefinisikan abu sebagai residu yang tersisa setelah pembakaran bahan bakar dalam tungku pembakar pada suhu tertentu. Ketika bahan bakar dibakar, bahan-bahan yang kurang volatil akan tertahan dalam abu bawah (bottom ashes) dan dedak halus abu layang (fly ash), sedangkan bahanbahan yang mudah menguap dengan suhu didih rendah akan mudah menguap pada suhu tinggi, dan masuk ke dalam fase gas.

Briket komposit arang bambulumpur yang dihasilkan dalam penelitian ini memiliki kadar abu yang bervariasi terhadap variasi komposisi briket di mana kadar abu cenderung meningkat dengan penambahan lumpur. Kadar abu terendah adalah $14,03 \%$ dan tertinggi adalah 39,65\% masing-masing untuk penambahan lumpur 4\% dan $40 \%$ (Gambar 3). Demikian pula halnya pada briket komposit arang jerami-lumpur. Kadar abu cenderung meningkat dengan meningkatnya komponen lumpur dalam campuran briket. Namun demikian, kadar abu yang ditunjukkan pada briket komposit arang jerami- lumpur jauh lebih besar dibandingkan dengan briket komposit arang bambulumpur. Nilai terendah kadar abu dari briket komposit arang jerami-lumpur adalah 50,96\% dan kandungan tertingginya adalah $60,09 \%$ berturutturut untuk penambahan lumpur $0 \%$ dan dengan penambahan lumpur $40 \%$ (Gambar 3).

Menurut FAO (1985), kadar abu arang kayu berkisar $0,5-5 \%$ atau dapat lebih dari 5\% tergantung pada jenis kayu (FAO, 1985). Menurut FAO (1987) kualitas arang yang baik umumnya memiliki kadar abu berkisar antara 3 sampai 4\%. FAO (1985) mengidentifikasi bahwa kadar abu arang yang dihasilkan dari kayu keras tropis berkisar antara 1,2\% sampai 8,9\%, ditegaskan pula bahwa briket dari arang yang lebih halus mungkin memiliki kandungan abu yang tinggi. SNI menetapkan kadar abu untuk briket arang $8 \%$, Jepang 3,6\%, Inggris menetapkan 5,9\%, dan Amerika menetapkan 8,3\% (Paisal dan Karyani, 2014).

Hasil penelitian ini menunjukkan bahwa berdasarkan kandungan abunya, semua briket yang dihasilkan tidak memenuhi standar kualitas briket. Penelitian ini juga menunjukkan bahwa kandungan abu pada arang jerami jauh lebih besar dibandingkan dengan pada arang bambu. Hal ini dimungkinkan karena pada jerami banyak terkandung oksida-oksida logam alkali. Oleh karena itu, hasil kadar abu briket arang dalam 
penelitian ini tampaknya benar. Disisi lain, konsumen briket arang akan lebih memilih briket dengan kandungan abu yang lebih rendah.

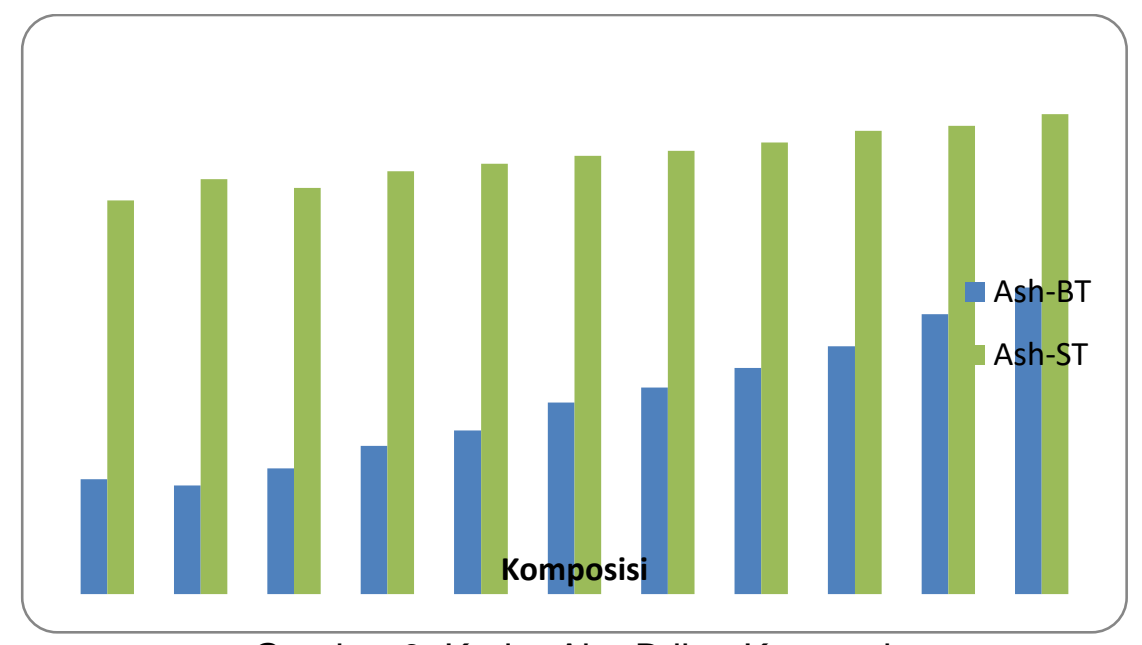

Gambar 3. Kadar Abu Briket Komposit

\begin{abstract}
Fixed carbon (FC) dalam briket komposit arang bambu-lumpur cenderung mengalami penurunan terhadap peningkatan komponen lumpur dalam campuran bahan baku. FC yang ditunjukkan oleh briket ini berkisar dari
\end{abstract} 38,38 hingga $61,30 \%$ masing-masing diperoleh dari penambahan lumpur sebanyak $40 \%$ dan tanpa penambahan lumpur (Gambar 7). Kandungan FC ini merupakan komponen tertinggi pada setiap briket komposit. Demikian pula halnya pada briket komposit arang jerami-lumpur kandungan FC briket komposit ini juga cenderung mengalami penuruan terhadap peningkatan jumlah lumpur yang ditambahkan. FC yang ditunjukkan oleh briket ini berkisar dari 17,65 hingga $27,47 \%$ masing-masing diperoleh dari penambahan lumpur sebanyak $40 \%$ dan tanpa penambahan lumpur (Gambar 4). Namun, pada keseluruhan dari briket komposit arang jerami-lumpur ini, FC merupakan komponen tertinggi kedua setelah abu. Menurut FAO (1985) FC arang kayu umumnya berkisar dari yang terendah sekitar $50 \%$ sampai yang tertinggi sekitar 95\%. Jadi kandungan utama arang adalah karbon. FAO (1985) merekomendasikan bahwa karbon arang yang dihasilkan dari campuran kayu keras tropis berkisar $68.6 \%$ hingga $69.8 \%$ jauh lebih tinggi bila dibandingkan dengan kandungan FC dari briket arang komposit yang dihasilkan dari penelitian ini. Adapun SNI mensyaratkan kandungan FC pada briket arang sebesar $77 \%$, sedangkan dalam peraturan menteri tidak dipersyaratkan.

FC bahan bakar adalah persentase yang tersedia pada arang pembakaran. Dengan kata lain, tidak sama dengan jumlah total karbon dalam bahan bakar (karbon ultimat) karena juga terdapat sejumlah signifikan karbon yang dilepaskan sebagai hidrokarbon dalam VM. Bahan bakar yang memiliki VM tinggi akan memiliki FC yang lebih rendah. Arang dengan kandungan FC lebih rendah cenderung akan lebih keras, berat, kuat, dan lebih mudah dinyalakan dibandingkan dengan arang dengan kandungan FC lebih tinggi (Riley, 2007). Namun demikian, khusus yang berkaitan dengan tingkat kekerasan, berat, dan kekuatannya juga dipengaruhi kandungan kadar abunya. Arang dengan kandungan kadar abu yang rendah cenderung lebih rendah tingkat kekerasan, berat, dan kekuatannya dibandingkan dengan arang dengan kandungan abu yang lebih tinggi. Artinya, briket arang yang lebih berat, lebih keras, lebih panjang pembakaran dan pemanasannya, serta tidak mudah hancur cenderung sulit untuk menyalakannya dibandingkan kondisi yang sebaliknya. 


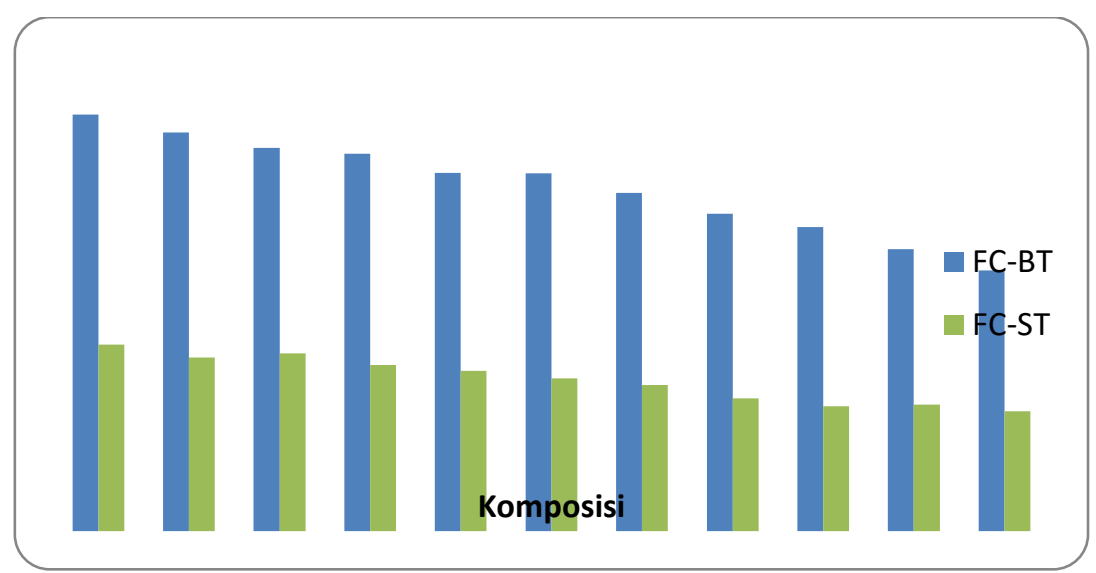

Gambar 4. Kadar Fixed Carbon Briket Komposit

Bila biomassa dikonversi secara thermal dengan jumlah udara berlebih (yaitu pembakaran) total energi yang dilepaskan dalam bentuk panas disebut nilai kalor atau nilai kalori. Nilai kalor biomassa umumnya dilaporkan dalam satuan $\mathrm{kJ} / \mathrm{kg}$. Bahan bakar minyak (premium) yang digunakan sebagai bahan bakar untuk menyalankan mesin pembakaran internal dilaporkan memiliki nilai kalor sekitar $43 \mathrm{MJ} / \mathrm{kg}$ (Kurdi dan Arijanto, 2007) dan solar memiliki nilai kalor sekitar sekitar $46 \mathrm{MJ} / \mathrm{kg}$ (Sitepu, 2009). Biomassa di sisi lain mungkin memiliki nilai kalor umumnya berkisar antara 15 - $25 \mathrm{MJ} / \mathrm{kg}$. Nilai kalor biasanya diukur dengan menggunakan calorimeter bomb.

Gambar 5 menunjukkan nilai kalor kedua briket komposit yang dihasilkan dari penelitian ini. Nilai kalor yang ditunjukkan dari briket komposit arang bambu-lumpur semakin rendah terhadap peningkatan jumlah lumpur yang ditambahkan. Nilai kalor terendah ditunjukkan oleh briket dengan komposisi lumpur $40 \%$ yakni sebesar $15,89 \mathrm{MJ} / \mathrm{kg}$. Nilai kalor tertinggi ditunjukkan oleh briket dengan komposisi lumpur 0\% yakni sebesar $24,96 \mathrm{MJ} / \mathrm{kg}$. Hal yang sama juga ditunjukkan oleh briket komposit arang jerami-lumpur, nilai kalornya cenderung menurun terhadap peningkatan jumlah lumpur yang ditambahkan. Nilai kalor terendah ditunjukkan oleh briket dengan komposisi lumpur $40 \%$ yakni sebesar $7,85 \mathrm{MJ} / \mathrm{kg}$. Nilai kalor tertinggi ditunjukkan oleh briket dengan komposisi lumpur 0\% yakni sebesar $11,94 \mathrm{MJ} / \mathrm{kg}$.

Perbedaan nilai kalor yang signifikan ditemukan antara briket komposit arang bambu-lumpur dengan arang jerami-lumpur. Perbedaan ini terutama diakibatkan oleh perbedaan kandungan abunya. Kandungan abu pada arang jerami jauh lebih besar dibandingkan dengan arang bambu. Adapun kandungan airnya relatif sama. Faktor lainnya yang juga dapat mempengaruhi nilai kalor adalah perbedaan kondisi operasi selama karbonisasi. Perbedaan suhu dalam proses karbonisasi juga salah satu faktor yang dapat berpengaruh secara signifikan pada nilai kalor (Thoha dan Fajrin, 2010).

Pada briket komposit arang bambu dan lumpur hanya 6 (enam) komposisi yang memenuhi persyaratan standar SNI berdasarkan nilai kalornya. Keenam briket komposit tersebut adalah briket dengan penambahan lumpur $0 \%$, $4 \%, 8 \%, 12 \%, 16 \%$, dan $20 \%$. Nilai kalor briket menurut spesifikasi yang ditetapkan oleh SNI adalah $5000 \mathrm{kcal} / \mathrm{kg}$ atau $21 \mathrm{MJ} / \mathrm{kg}$. Adapun bila dibandingkan dengan standar Jepang $(6000-7000 \mathrm{kcal} / \mathrm{kg})$, Inggris (7289 $\mathrm{kcal} / \mathrm{kg}$ ), dan Amerika (6230 kcal $/ \mathrm{kg}$ ), nilai kalor pada semua komposisi tidak memenuhi persyaratan yang ditentukan. Pada briket komposit arang jeramilumpur, tidak satupun standar yang dipenuhi terkait dengan nilai kalornya. 


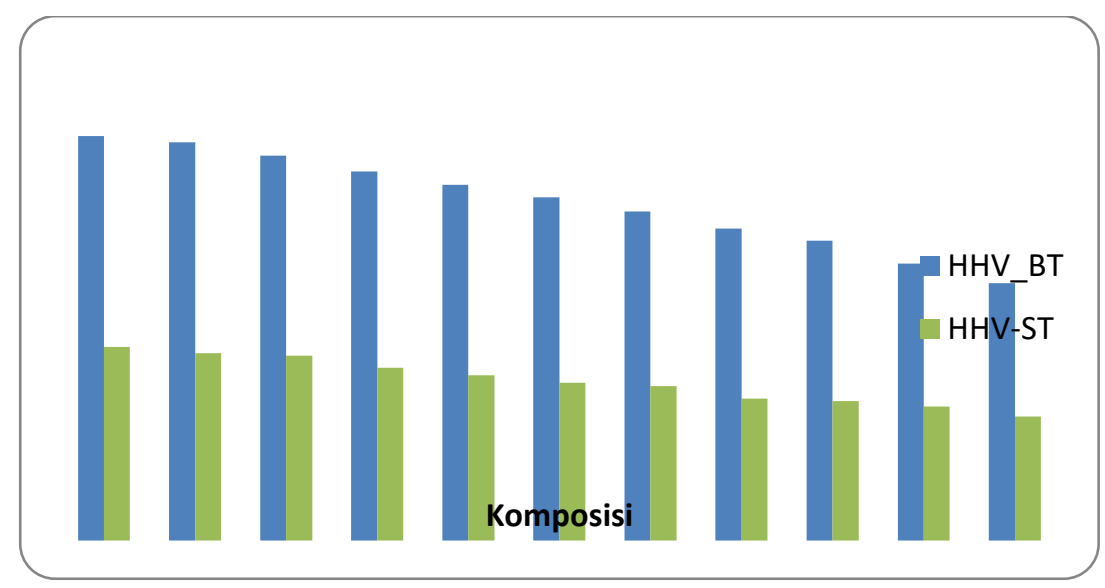

Gambar 5. Nilai Kalor Briket Komposit

\section{PENUTUP}

Hasil dari penelitian ini menunjukkan bahwa semakin banyak lumpur limbah perkotaan yang ditambahkan maka semakin tinggi kadar abu dan semakin rendah fixed carbon dari briket yang dihasilkan. Dengan kata lain penambahan lumpur limbah perkotaan berpengaruh signifikan terhadap kadungan kadar abu dan fixed carbon tetapi tidak berpengaruh signifikan terhadap kandungan volatile matter briket. Peningkatan kandungan abu dan penurunan fixed carbon dengan penambahan lumpur telah berakibat pada semakin rendah kandungan energi dari briket. Dengan demikian, lumpur limbah perkotaan kurang sesuai digunakan sebagai bahan briket.

\section{DAFTAR PUSTAKA}

ASTM Standard D2015-85, Standard test method for gross calorific value of coal and coke by the adiabatic bomb calorimeter, in gaseous fuel; coal and coke, section 5, vol. 0.5-05, ASTM International,

West Conshohocken, PA, 1989:251.

ASTM Standard D2016-77, Standard test method for moisture in the analysis sample of wood and wood material, approved for sample, section 5, vol 05-05; annual book of standard, ASTM International,

West Conshohocken, PA, 1989:300.
ASTM Standard D3172-73(Reapproved 1984), Standard method of proximate analysis of coal and coke, in Gaseous fuels; coal and coke, section 5, vol .05-05; Annual book of ASTM standard, ASTM International, West Conshohocken, PA, 1984: 299.

ASTM Standard D3174-89, Standard test method for ash in the analysis sample of coal and coke, in gaseous fuels; coal and coke, section 5, vol. 05, ASTM International, West Conshohocken, PA, 1989: 302.

ASTM Standard D3175-89, Standard test method for volatile matter in the analysis sample of coal and coke, in gaseous fuel, coal and coke, section 5, vol. 05-05; ASTM International, West Conshohocken, PA, 1989: 305.

FAO, 1985. Industrial charcoal making. Food and Agriculture Organization of the United Nations. Rome, Italy.

Processing Technology, vol. 54, pp. 17-46.

Paisal dan Karyani,M.S. 2014. Analisis Kualitas Briket Arang Kulit Durian dengan Campuran Kulit Pisang Pada Berbagai Komposisi Sebagai Bahan Bakar Alternatif. Proceeding Seminar Nasional Teknik Mesin Universitas Trisakti, 20 Februari 2014. FTI-Usakti Jakarta. 
Pallavi, H.V., Srikantaswamy, S., Kiran, B.M., Vyshnavi, D.R., And Ashwin, C.A. 2013. Briquetting Agicultural Waste as Energy Source. Journal of Environmental Science, Computer Science and Engineering \& Technology. Vol.2.No.1, 160-172. Tersedia Online Pada Www.Jecet.Org

Riley, 2007. Routine Coal and Coke Analysis: Collection, Interpretation, and Use of Analytical Data. ASTM International. U.S.A.

Singh, R.N., 2004. Equilibrium moisture content of biomass briquettes. Biomass and Bioenergy, 26 (2004): 251-253.

Sriharti Dan Salim, T. 2011. Pengaruh Komposisi Bahan Terhadap Karakterisasi Briket Limbah Biji Jarak Pagar (Jatropha Curcas Linn). Teknologi Indonesia. Vol 34, 40-48 